\title{
Being White
}

\author{
Luanne Armstrong
}

\begin{abstract}
Être blanche
Dans un cercle de femmes, une dit: "je suis fière d'être moi-même. Je suis fière d'être Indienne." Je suis silente. Je suis blanche, n'ai pas honte, mais n'est pas capable d'en dire que je suis fière de l'être ... Je suis née blanche et la honte n'en est pas l'enjeu. Plutôt j'essaie de comprendre, à la lumière d'Oka, et Kahnasetake avec tout ce que je connais au sujet des réclamations du territoire, de l'école residentielle, de l'arrogance des blancs autour de moi, à la lumière de l'histoire de la Colonisation, et de ce que mes étudiant-e-s m'ont enseigné là-dessus - ce qu'est vraiment notre histoire d'impérialistes. Vivreavec une autreculture est être touriste, détachée des complexités de sa propre culture. Mais la frontière est perméable entre le visiteur-e et l'envahisseur-e. J'essaie de me rapeller continuellement que je ne suis qu'une visiteure et de prendre la responsabilité pour mes actes, pour me changer et pour changer le monde. Il faut arrêter de chercher la compréhension, la sympathie auprès des gens que nous avons tant abusés. Les autres cultures ne nous doivent rien. C'est à nous d'examiner - et de changer - nos assomptions ethnocentriques.
\end{abstract}

I am sitting in a circle with other women, talking. This is familiar, comfortable, sitting, talking with other women. Then one woman says, "I am proud of who I am, proud of my family, proud of being a woman, proud of being Indian." I am silent. I am white, not ashamed of it, but not able to say, in the same way, that it's something I'm proud of. Nor, I think to myself, could a man sitting here say that he was proud of being a man. Its not the same.

In our society, we expect victims to fix the situations that have hurt them; we expect oppressed people to define themselves in opposition to their oppressors. Now, I ask myself for the first time in my life, what does it mean to be white. What does it mean to me, especially in this time in my life, when I walk in at work, a white teacher, to a classroom of aborig- 
inal people. As their English teacher, I have the power and the privilege of asking for, and listening to, and reading their stories. I get to witness, hear and read about the pain of what has happened to them, what has been done to them.

In order to walk into such a room, I have spent time trying to undo any assumptions that I might have about who Native people are. And now I have run into a hidden assumption that Ihave never looked at before, the assumption that I don't need to analyze for myself what it means to be white.

As a woman in this society, as a feminist,I have spent the past fifteen years examining what it means to be female. I have read women's history, what there is of it, examined our condition, our place in society, our culture, our economic conditions, and dreamed and visioned about how the world might be transformed.

With other women, I have talked about, and listened to, and looked at, and tried to help create a new kind of culture ... a women's culture. Within this broad framework, I have examined other aspects of myself, what it means to be a member of my family, to be rural, to be a mother, a writer, a teacher, a lesbian.

Now, having seen myself, all my life, as a member of oppressed groups, as poor, rural, female, I walk everyday into a room as white, educated, teacher. A person with power, whether or not I choose to exercise it. It's a reality I would be lying to deny. Yes, there are similarities in our background and points of connection, but not samenesses. I am not Indian. Nor will I pretend to understand what it might mean to be so. I try, as far as it is possible, to be a friend, to not make too many mistakes and learn what there is for me to learn.

Nor does it work, for me, to walk in ashamed of being white. I was born white, born to my heritage and culture, such as it is, and shaming myself for what I am seems pointless. Instead, I am trying to understand, in the light of Oka, Kahnewake and Kahnasetake, in the light of what I know now about land claims, and residential school, about the arrogance and the assumptions of white people all around me, in the light of colonization and in light of what my students have taught me, - what really happened in our history.

To live with another culture is partly a relief; it means being able to give up, for a while, the perplexities and shadows of one's own culture, means being able to be a tourist, a visitor. One sees the same landscape from a very different perspective. 
But a tourist, a visitor, an intruder, are just a thin line away from each other. As a tourist, it's necessary to come as a guest, courteous, and willing to learn. For the culture one comes into has, or should have the right to decide finally whether or not your behaviour is intrusive, whether you stay or go.

But that is a right which colonization and conquest usurped. We people of European descent are here, and here to stay. People of many cultural heritages are now here as well. Here is our home, we say. History says we took it, "conquered" it, never asking questions or permission of anyone, hungry people, coming into a "new land" and leaving our own behind. We insisted on our right to go everywhere, collecting songs, stories, myths that aren't ours, bits and pieces of culture to make up for the vacancies in our own, collecting artifacts and history and dead bones, and making up the symbols and the stereotypes to suit ourselves and our own mythology.

Part of my process now, and its a long one, is to ask what this history means to me now. Part of my process is to check in, every day, with the sense of being an intruder, and remind myself to behave as a guest.

"You're just like a wild Indian," my mother used to say, when I was a child. I would feel proud. I wanted to be free and live in the woods. What I knew about Indians came from books and comics. Ironically, the only Indian I really knew was the mother of my two girlfriends who lived up the road. They were slightly older than me. They taught me to ride horses and smoke cigarettes in our hideout. Mabel was just their mother, and what did mothers/women know, I thought then. Theirs was the tyranny of helpless passivity which I wanted nothing to do with.

Now, sometimes I think of Mabel, and I miss what I never knew. I see her sad calm face reflected in some of the faces around me, and I wonder now, where was her home, her family. She had eighteen children, was married to a brutal drunken Irishman until he died, still lives in my hometown and when I see her, we stop and chat and catch up on the news. But who is she? What did she think and know and see when I was learning about the world. She was then, for me, invisible.

As a white person, I have so often lost by being too fast, too rushed, too invincible, and too sure of myself. I see my behaviour reflected in others. What will finally make us question our/my arrogance?

I look around at the other white faces at work, and I know many of us wrestle with being here, with similar feelings of intrusion, with our own ignorance, with our right to be here at all. 
Why is it, in fact, so difficult to understand what it means to be white. Is this how men feel in relation to women? Do they have the same difficulty in understanding themselves in relation to women. Do they feel separated from us, excluded by their own sense of universality? Does to be powerful mean then to be excluded from the solidarity and culture of those lower on the hierarchy? Does to be powerful mean to be less and less defined? Is this a promise of freedom that turns hollow when it's achieved? Is this the part of the whole we try to fill in ourselves by absorbing and adopting bits and piecemeal parts of other cultures?

Contemporary friends who find out I work at a Native college invariably mention the subject of Native spirituality. Sometimes they have studied it, or are "into" it, or know something about it, or have a best friend who is into it, or even a best friend who is Indian. Invariably I am silent on the subject. I know so little. I know what I have heard and experienced. I know my own spirituality, which is Wiccan, and similar. But not, again, the same.

Being white means I get into conversations like this. It means I also invariably get into conversations about what racism is, that I end up explaining about residential schools, and issues like appropriation of culture, and why I won't read Lynn Andrews, and why W.P. Kinsella had no right to write what he did, and what it feels like to hear, over and over, what white people have done and continue to do to Native people. And I know I don't hear the half of it. I hear the words, but I don't and can't know, what it feels like to live on the other side of the racism in this country.

Being white means, I think, much the same as what I told my sons about being male. It means taking responsibility for the class and the context one is born into, for not being racist, and not being sexist. In order not to do that, I told them, you have to understand who you are in relationship to the people you have the potential to oppress. I have to understand that. It sounds so simple, at least when I say it to men. It's not up to women, I have said to some of them, to explain to you when you're being oppressive. Nor is it up to my students or my colleagues to do that for me. But when I turn the light upon myself, it feels like a long and vague and difficult task.

What do I need to know? How to behave? How to be courteous? How to listen? I'm not sure of all of it. I make many mistakes. Perhaps whiteness is something I carry with me, like a flag, like a contagion. Perhaps no matter how careful I am, I am bound to fail, to make mistakes. I can't after 
all, be other than what I am. That's the burden we get to carry, the white "man's" burden, only ironically turned upside down and inwards, the product of our years of history and exploitation and colonialization. I can't say it's not mine, any more than my wonderful sons can protest that they are nice men and not oppressors. It's built into the system, and we are all part of it. You are men, I say to them, and must be responsible, stop other men from being violent and cruel. It is never the victim's task to fix the circumstances of her victimization. She can fight back, or leave, but she didn't create the situation, and it is a double form of oppression to ask her to be responsible for undoing it.

Indian people can't fix or save white people. Only we can do that and we're damned slow. Indian spirituality won't save the earth, either, although it has a lot to teach us. We have to do it ourselves, the slow boring way, by knowledge and understanding and analysis. We must also learn what it means to be white, what we've done, where it was wrong, and how and why not to do it again.

We have to begin and continue together the analysis and understanding of what it means to be white, and in so doing, begin the understanding and analysis of who we are in relation to our own past, which included what we have done to other people, other cultures. We have to stop our earnest and dishonest efforts to be understood and accepted by people we have abused in the past. Instead, we must continue the process of understanding and healing ourselves; begin, as far as is possible, from a place of equality, from doing away with our usual stance, our usual assumptions that it is we who are the measure, the norm, and therefore, unassailable. Other cultures have no responsibility to understand us, or change us, or even bother with us at all. That's our task, and it's difficult. Far from impossible though, and necessary. 